\title{
Content Usage and the Most Frequently Read Articles by Issue in 2012
}

Phillip Lupo, Jr., MLIS, Anne Victoria Neale, PhD, MPH, and Marjorie A. Bowman, MD, MPA

We are pleased to provide feedback about the fournal of the American Board of Family Medicine $(7 A B F M)$ articles published in 2012 that were of the greatest interest to our readers. Table 1 shows the 3 most frequently read articles by issue in $2012 .{ }^{1-18}$

Conflict of interest: The authors are editors and staff of the 7ABFM.
Clinical reviews and original research proved to be the most-read types of articles.

In addition, we provide an update on the usage statistics of our content over the last 7 years. Figure 1 illustrates the number of total access events for FABFM content from 2006 to 2012. The latter was the busiest year for online activity in the history of the $7 A B F M$, with an average of 290,000 monthly

Figure 1. The number of total access events for Journal of the American Board of Family Medicine content from 2006 to 2012. (Data source: Access events for content for the Journal of the American Board of Family Medicine, by year, by HighWire Press (updated monthly). Access events for content are based on hits received on the Journal of the American Board of Family Medicine website only. Accessed March 15, 2013.)

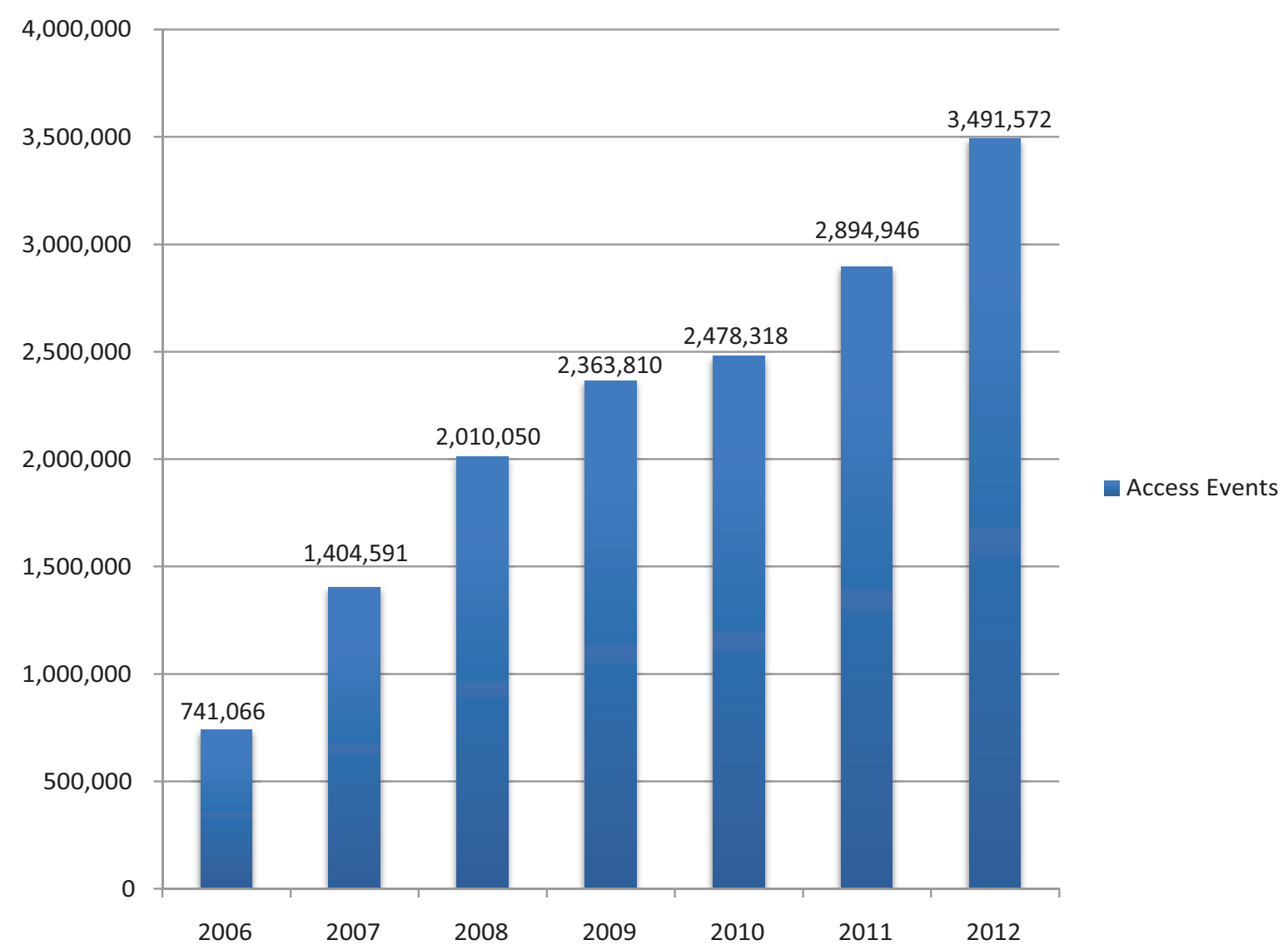


Table 1. The 3 Most Frequently Read Articles in the Journal of the American Board of Family Medicine in 2012, by Issue

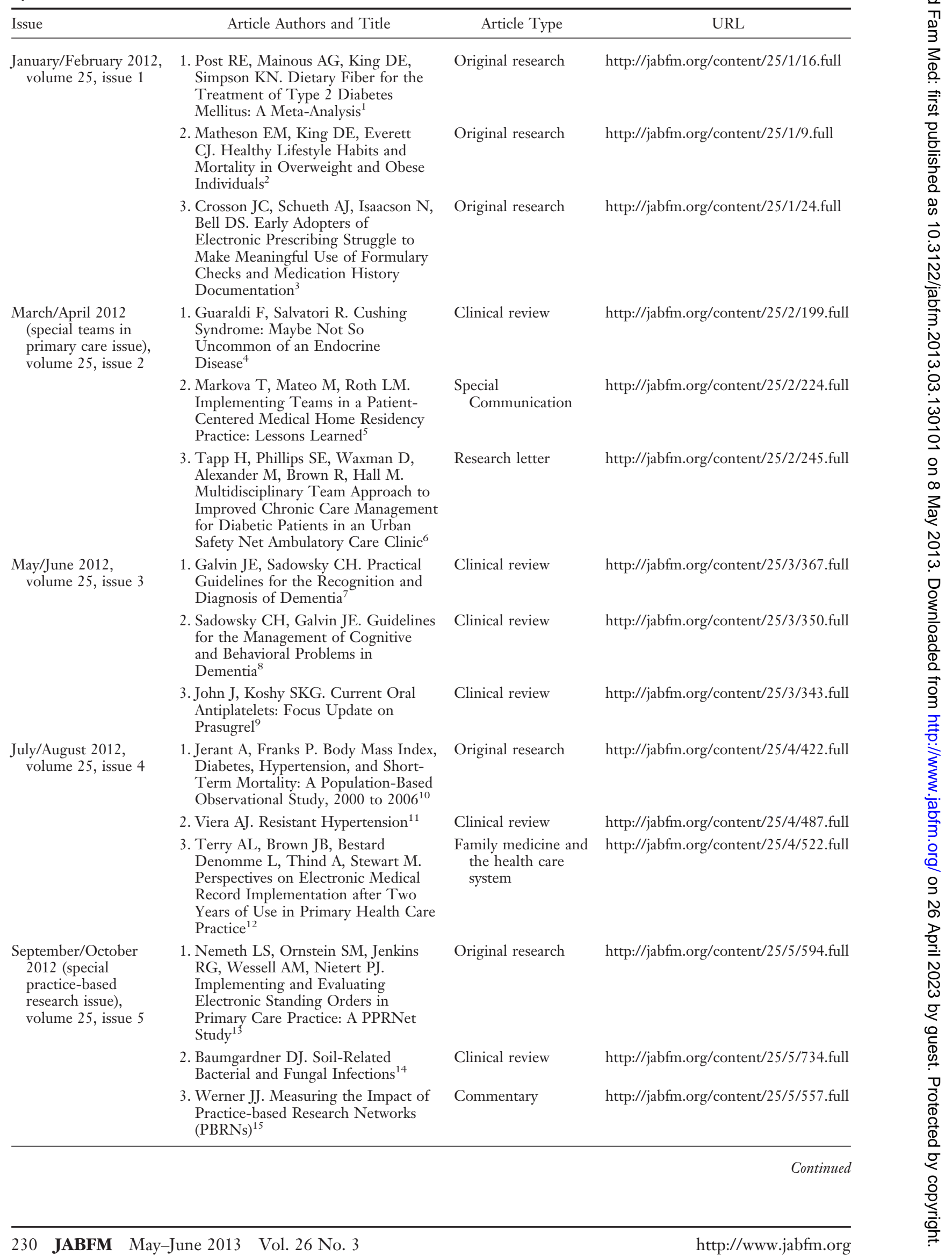


Table 1. Continued

\begin{tabular}{|c|c|c|c|}
\hline Issue & Article Authors and Title & Article Type & URL \\
\hline \multirow[t]{3}{*}{$\begin{array}{l}\text { November/December } \\
2012 \text {, volume } 25 \text {, } \\
\text { issue } 6\end{array}$} & $\begin{array}{l}\text { 1. Hines JL, King TS, Curry WJ. The } \\
\text { Adult ADHD Self-Report Scale for } \\
\text { Screening for Adult Attention } \\
\text { Deficit-Hyperactivity Disorder } \\
(\text { ADHD })^{16}\end{array}$ & Original research & http://jabfm.org/content/25/6/847.full \\
\hline & $\begin{array}{l}\text { 2. Hamrick I. More House Calls by } \\
\text { Fewer Physicians }{ }^{17}\end{array}$ & Commentary & http://jabfm.org/content/25/6/759.full \\
\hline & $\begin{array}{l}\text { 3. Mold JW, Holtzclaw BJ, McCarthy } \\
\text { L. Night Sweats: A Systematic } \\
\text { Review of the Literature }\end{array}$ & Clinical review & http://jabfm.org/content/25/6/878.full \\
\hline
\end{tabular}

HighWire Press (updated monthly). Rankings are based on hits received by articles archived on the fournal of the American Board of Family Medicine website only. Accessed March 15, 2013.

and a total of 3.49 million yearly content usage requests. Content activity was up $21 \%$ in 2012 compared with content usage requests during 2011, and when compared with 2006, a $149 \%$ increase is noted. Full-text articles were accessed most during 2012 , with an average of 110,403 monthly requests, followed by abstracts, with 88,342 average monthly requests, and then PDF articles, with 49,836 average monthly requests.

As always, we welcome reader feedback about published articles. Comments about specific articles can be posted to the $7 A B F M$ website by clicking on "Responses" in the middle column of the article.

\section{References}

1. Post RE, Mainous AG, King DE, Simpson KN. Dietary fiber for the treatment of type 2 diabetes mellitus: a meta-analysis. J Am Board Fam Med 2012;25:16-23.

2. Matheson EM, King DE, Everett CJ. Healthy lifestyle habits and mortality in overweight and obese individuals. J Am Board Fam Med 2012;25:9-15.

3. Crosson JC, Schueth AJ, Isaacson N, Bell DS. Early adopters of electronic prescribing struggle to make meaningful use of formulary checks and medication history documentation. J Am Board Fam Med 2012; 25:24-32.

4. Guaraldi F, Salvatori R. Cushing syndrome: maybe not so uncommon of an endocrine disease. J Am Board Fam Med 2012;25:199-208.

5. Markova T, Mateo M, Roth LM. Implementing teams in a patient-centered medical home residency practice: lessons learned. J Am Board Fam Med 2012;25:224-31.

6. Tapp H, Phillips SE, Waxman D, Alexander M, Brown R, Hall M. Multidisciplinary team approach to improved chronic care management for diabetic patients in an urban safety net ambulatory care clinic. J Am Board Fam Med 2012;25:245-6.

7. Galvin JE, Sadowsky CH. Practical guidelines for the recognition and diagnosis of dementia. J Am Board Fam Med 2012;25:367-82.

8. Sadowsky CH, Galvin JE. Guidelines for the management of cognitive and behavioral problems in dementia. J Am Board Fam Med 2012;25:350-66.

9. John J, Koshy SKG. Current oral antiplatelets: focus update on prasugrel. J Am Board Fam Med 2012;25:343-9.

10. Jerant A, Franks P. Body mass index, diabetes, hypertension, and short-term mortality: a populationbased observational study, 2000-2006. J Am Board Fam Med 2012;25:422-31.

11. Viera AJ. Resistant hypertension. J Am Board Fam Med 2012;25:487-95.

12. Terry AL, Brown JB, Bestard Denomme L, Thind A, Stewart M. Perspectives on electronic medical record implementation after two years of use in primary health care practice. J Am Board Fam Med 2012;25:522-7.

13. Nemeth LS, Ornstein SM, Jenkins RG, Wessell AM, Nietert PJ. Implementing and evaluating electronic standing orders in primary care practice: a PPRNet study. J Am Board Fam Med 2012; 25:594-604.

14. Baumgardner DJ. Soil-related bacterial and fungal infections. J Am Board Fam Med 2012;25:734-44.

15. Werner JJ. Measuring the impact of practice-based research networks (PBRNs). J Am Board Fam Med 2012;25:557-9.

16. Hines JL, King TS, Curry WJ. The adult ADHD self-report scale for screening for adult attention deficit-hyperactivity disorder (ADHD). J Am Board Fam Med 2012;25:847-53.

17. Hamrick I. More house calls by fewer physicians. J Am Board Fam Med 2012;25:759-60.

18. Mold JW, Holtzclaw BJ, McCarthy L. Night sweats: a systematic review of the literature. J Am Board Fam Med 2012;25:878-93. 